\title{
Diversity of larvae of littoral Chironomidae (Diptera: Insecta) and their role as bioindicators in urban reservoirs of different trophic levels
}

\author{
Morais, SS. ${ }^{\mathrm{a} \dagger}$, Molozzi, J. ${ }^{\mathrm{a}}$,Viana, AL. ${ }^{\mathrm{a}}$, Viana, $T H .{ }^{\mathrm{b}}$ and Callisto, M. ${ }^{\mathrm{a}}{ }^{*}$ \\ ${ }^{a}$ Laboratório de Ecologia de Bentos, Departamento de Biologia Geral, \\ Instituto de Ciências Biológicas - ICB, Universidade Federal de Minas Gerais - UFMG, \\ Av. Antônio Carlos, 6627, Pampulha, CP 486, CEP 30161-970, Belo Horizonte, MG, Brazil \\ ${ }^{\mathrm{b} C o m p a n h i a}$ de Saneamento de Minas Gerais - COPASA, Rua Mar de Espanha, \\ 525, Bairro Santo Antônio, CEP 30330-900, Belo Horizonte, MG, Brazil \\ In memorian \\ *e-mail: callistom@ufmg.br
}

Received September 10, 2009 - Accepted November 30, 2009 - Distributed November 30, 2010

(With 2 figures)

\begin{abstract}
The Chironomidae (Diptera: Insecta) have a high species richness, with species adapted to live under widely different environmental conditions. The study of the taxonomic composition of chironomid larvae and the percentage of occurrence of deformities in mouthparts, mainly in the mentum, are used in biomonitoring programmes in order to obtain information on the levels of organic and chemical pollution of aquatic ecosystems. The objective of this study was to evaluate the abundance of chironomid larvae and to quantify the occurrence of mentum deformities in the specimens collected in three urban reservoirs with different trophic levels. The reservoirs are located in the hydrographic basin of the Paraopeba River, an affluent of the São Francisco River basin (Minas Gerais State, southeastern Brazil). The Serra Azul Reservoir is oligotrophic, the Vargem das Flores Reservoir is mesotrophic, and the Ibirité Reservoir is eutrophic. Along the littoral zone of each reservoir, 30 samples were collected during each sampling campaign. Sampling was carried out every three months for one year, with two sampling campaigns during the wet season and two during the dry season in 2008. Physical and chemical parameters measured in the water column included the water depth, Secchi depth, air and water temperature, electrical conductivity, total dissolved solids, redox potential, dissolved oxygen, $\mathrm{pH}$, turbidity, Total-N, Total-P, P-ortho, and chlorophyll- $a$. The chironomid larvae were identified to the genus level. The structure of the chironomid assemblages was evaluated based on taxonomic richness ( 24 genera), density, equitability, and diversity. The potential indicator taxa for each reservoir were established through an Indicator Species Analysis. The values for taxonomic richness (20 taxa), equitability (0.737), and Shannon-Wiener diversity (2.215) were highest in the Serra Azul Reservoir. Fissimentum was the indicator taxon in Serra Azul, the oligotrophic reservoir; whereas Pelomus was the indicator taxon in Vargem das Flores, and Chironomus in Ibirité. The highest percentage of mentum deformities was found during the dry season in Serra Azul (6.9\%), while the lowest percentage was found during the wet season in Vargem das Flores (0.8\%). The results of this study evidenced significant differences in the taxonomic composition, richness, equitability, and diversity of the chironomid assemblages in these three reservoirs of different trophic levels.
\end{abstract}

Keywords: taxonomic composition, indicator taxa, Chironomidae deformities.

\section{Diversidade de larvas de Chironomidae (Diptera: Insecta) e seu papel como bioindicadores na região litorânea de reservatórios urbanos em diferentes níveis tróficos}

\section{Resumo}

Os Chironomidae (Diptera-Insecta) apresentam ampla riqueza de espécies e adaptam-se a diferentes condições ambientais. O estudo da composição taxonômica de larvas de Chironomidae e o percentual de ocorrência de deformidades encontrado em peças do aparelho bucal, principalmente no mento, são utilizados em programas de biomonitoramento para obter informações a respeito do nível de poluição orgânica e química em ecossistemas aquáticos. O objetivo deste estudo foi avaliar a abundância e quantificar a ocorrência de deformidades no mento de larvas de Chironomidae coletadas em três reservatórios urbanos em diferentes estados tróficos na bacia hidrográfica do rio Paraopeba, afluente da bacia do rio São Francisco (MG). O estudo foi desenvolvido nos reservatórios de Serra Azul (oligotrófico), Vargem das Flores (mesotrófico) e Ibirité (eutrófico). Foram coletadas 30 amostras na região litorânea de cada reservatório, ao longo de todo perímetro, trimestralmente, ao longo de um ano (duas coletas na estação seca e duas na chuvosa). Algumas variáveis físicas e químicas (profundidade, Secchi, temperatura do ar e da água, condutividade elétrica, sólidos totais dissolvidos, 
potencial oxi-redox, oxigênio dissolvido, $\mathrm{pH}$, turbidez, N-total, P-total, P-orto e clorofila- $a$ ) foram mensuradas na coluna d'água. As larvas de Chironomidae foram identificadas até o nível de gênero. A estrutura das assembleias de Chironomidae foi avaliada com base na riqueza taxonômica (24 gêneros), densidade, equitabilidade e diversidade. Foram estimados os táxons indicadores em cada reservatório através de uma análise de espécies indicadoras. Os valores de riqueza taxonômica (20 táxons), equitabilidade $(0,737)$ e diversidade de Shannon-Wiener $(2,215)$ foram maiores em Serra Azul do que nos outros reservatórios. Fissimentum foi o táxon indicador no reservatório de Serra Azul, Pelomus no reservatório de Vargem das Flores e Chironomus no reservatório de Ibirité. O maior percentual de deformidades no mento das larvas foi encontrado no reservatório de Serra Azul na estação seca (6,9\%), enquanto o menor percentual foi reportado no reservatório de Vargem das Flores na estação chuvosa $(0,8 \%)$. Os resultados deste estudo evidenciaram diferenças significativas entre a composição taxonômica, riqueza, equitabilidade e diversidade nos três reservatórios em diferentes níveis tróficos, corroborando o papel das larvas de Chironomidae como bioindicadoras.

Palavras-chave: composição taxonômica, táxons indicadores, deformidades em Chironomidae.

\section{Introduction}

Reservoirs are artificial ecosystems, and their ecological functioning has intermediate characteristics between rivers and lakes (Tundisi et al., 1998). Reservoirs are constructed in order to provide water reserves for different purposes including the production of electricity, household and industrial supplies, transport, irrigation, and recreation (Branco and Rocha, 1977; Tundisi et al., 2008). Reservoirs are distinct landscape features, and in Brazil their surrounding areas are often the target of uncontrolled human occupation (Tundisi, 2006). Anthropogenic reservoir eutrophication leads to an increase in nutrient concentrations (nitrogen and phosphorus) and to the alteration of physical and chemical water parameters (temperature, dissolved oxygen, $\mathrm{pH}$, electrical conductivity), causing reduction of the aquatic biodiversity (Camargo et al., 2005) and often cyanobacterial blooms (Costa et al., 2006; Conley et al., 2009).

Freshwater bioindicators are species, groups of species, or biological communities whose presence, density, and distribution indicate the magnitude of environmental impacts in an aquatic ecosystem and its catchment basin (Bonada et al., 2006). Biological communities reflect the ecological integrity of their ecosystems, integrating the effects of different impacting agents and providing an aggregate measure of the impact of these agents (Barbour et al., 1999). Biological indicators of water quality offer important advantages over physical and chemical parameters, since they represent environmental conditions obtained over periods of time, whereas physical and chemical data are instant measurements that reflect only the present conditions in the aquatic ecosystems (Callisto et al., 2005a).

There are many biological indicators of ecological conditions in freshwater ecosystems. The most frequently used are the benthic macroinvertebrates (Karr, 1991; Piedras et al., 2006). These organisms are widely used in biomonitoring programmes because they directly reflect environmental changes in aquatic ecosystems and their catchments; they are sedentary, diverse, and abundant; and they have long life cycles, which allow some temporal and spatial stability (Rosenberg and Resh, 1993).
Studies of reservoir water quality using benthic macroinvertebrates have contributed to increased ecological knowledge of the communities of these aquatic ecosystems (Roque et al., 2004; Moreno and Callisto, 2006; Jorcin et al., 2009). In many Brazilian reservoirs, the benthic communities are represented by three main groups: Oligochaeta, Mollusca, and larvae of Chironomidae (Pamplin et al., 2006; Jorcin and Nogueira, 2008). Chironomid larvae comprise a prominent part of the benthic macrofauna because of their high species richness and adaptability to different environmental conditions (Oliver, 1971; Coffman and Ferrington Jr, 1996; Callisto et al., 2002).

Many studies have demonstrated that the physical and chemical parameters of the water influence chironomid composition and abundance (Oliver, 1971; Botts, 1997; Helson et al., 2006; Entrekin et al., 2007). The success of this family in exploiting a wide rage of trophic conditions in aquatic ecosystems is a consequence of its great capacity for physiological adaptation, which allows the individuals to live in environments where temperature, $\mathrm{pH}$, dissolved oxygen concentration, pollution, salinity, depth, and productivity are variable (Helson et al., 2006; Entrekin et al., 2007). As a result, these organisms are able to colonise many types of substrates in high densities (Berg and Hellenthal, 1992; Tokeshi, 1995; Huryn and Wallace, 2000). These characteristics make chironomids efficient organisms for the evaluation of water quality in Neotropical reservoirs (Takahashi et al., 2008).

Reports on morphological abnormalities in the heads of chironomid larvae collected in polluted environments suggest a relationship between these deformities and pollution (Lenat, 1993; Vermeulen, 1995; Janssens de Bisthoven et al., 1998; Servia et al., 2000). The deformities are reported to be more frequent in more-polluted aquatic ecosystems, and some studies have used their frequency as an indicator of severe pollution (Servia et al., 2000; Martinez et al., 2002). These deformities occur at different intensities in the antenna and mouthparts, mainly in the mentum, when the larvae are exposed to heavy metals, agricultural pesticides and fertilisers, and industrial 
pollutants, among others (MacDonald and Taylor, 2006; Sanseverino and Nessimian, 2008).

The objective of this study was to evaluate the taxonomic composition, distribution, and abundance of chironomid larvae, as well as to quantify the occurrence of mentum deformities in specimens collected in three reservoirs of different trophic levels. The hypothesis was that human activities in the catchment basin of a reservoir alter the composition and structure (richness, equitability, and diversity) of the chironomid assemblages in the littoral zone of reservoirs, and can cause morphological deformities in the mouthpart structures of these organisms.

Because the level of degradation of a reservoir is usually related to its trophic status, we predicted that: i) the oligotrophic reservoir, well preserved and relatively unimpacted, will show higher richness and equitability than the mesotrophic and eutrophic reservoirs, which are impacted by industrial activities and by the disposal of domestic sewage; ii) a higher frequency of occurrence of morphological deformities in the mentum of chironomid larvae will be observed in the mesotrophic and eutrophic reservoirs; and iii) the mesotrophic and eutrophic reservoirs will have high nutrient contents in the water, and pollutiontolerant taxa; whereas the oligotrophic reservoir will have low nutrient contents and pollution-sensitive taxa.

\section{Material and Methods}

\subsection{Study area}

The study was carried out in three reservoirs located in the catchment of the Paraopeba River, an affluent of the São Francisco River basin (Minas Gerais State, Brazil) (Figure 1).

The Ibirité Reservoir (19 $07^{\circ} 00^{\prime}-20^{\circ} 02^{\prime} 30^{\prime \prime} \mathrm{S}$ and $44^{\circ} 07^{\prime} 30-44^{\circ} 05^{\prime} 00^{\prime} \mathrm{W}$ ) is formed by the influx of the Pintado and Retiro do Onça rivers. It is affected by intense human impacts such as the disposal of domestic sewage and the presence of unorganised human settlements in its surroundings. As a consequence, this ecosystem shows advanced artificial eutrophication (Callisto et al., 2005b; Moreno and Callisto, 2006). The reservoir has a surface area of $2.8 \mathrm{~km}^{2}$, a volume of 15,423,000 $\mathrm{m}^{3}$ and a mean depth of $16 \mathrm{~m}$ (Rodrigues, 2004).

The Vargem das Flores Reservoir (19० 53' 30', $19^{\circ} 55^{\prime} 25^{\prime \prime} \mathrm{S}$ and $44^{\circ} 07^{\prime} 22^{\prime \prime}$ and $44^{\circ} 10^{\prime} 59^{\prime \prime} \mathrm{W}$ ) is fed by Betim Creek. It has moderate human occupancy in its surroundings and is, together with the Serra Azul Reservoir, one of the main sources of water supply for the Belo Horizonte metropolitan region. It is a mesotrophic ecosystem, with a surface of $5.5 \mathrm{~km}^{2}$, a volume of $44,000,000$ $\mathrm{m}^{3}$, a mean depth of $6 \mathrm{~m}$, and a maximum depth of $18 \mathrm{~m}$ (COPASA, 2004).

The Serra Azul Reservoir (1954'09” - 20 00' 52' S and $44^{\circ} 23^{\prime} 16^{\prime \prime}-44^{\circ} 30^{\prime} 20^{\prime}$ ' W) is fed by Juatuba Creek. It is located on the boundary between the Juatuba and the Mateus Leme municipalities. It is an oligotrophic ecosystem, with a surface of $8.9 \mathrm{~km}^{2}$, a volume of $93,000,000 \mathrm{~m}^{3}$ and a maximum depth of $40 \mathrm{~m}$ (COPASA, 2004). The sediment has high manganese levels due to its geomorphologic origin (Martins, 1996).

\subsection{Field methods and laboratory analyses}

The reservoirs were sampled every three months in 2008, during the dry season (June and September) and during the wet season (March and December). Along the littoral zone of each reservoir, 30 samples were collected, using an Eckman-Birge $\left(0.0225 \mathrm{~m}^{2}\right)$ sampler. The samples were deposited in plastic bags and transported to the laboratory, where they were washed on sieves of $1 \mathrm{~mm}$ and $0.5 \mathrm{~mm}$ meshes (Larsen et al., 1991). Sub-surface water samples were collected using Van Dorn bottles, for the measurement of the physical and chemical parameters. The physical and chemical parameters of the surface water $(\mathrm{pH}$, temperature, dissolved oxygen, electrical conductivity, and turbidity) were measured in situ, using a multi-analyser and portable apparatus (YSI). The Secchi disc was used to evaluate the depth of the trophic zone. For the measurements of total nitrogen, total phosphorus, and orthophosphate, 30 water samples were collected from each reservoir and transported to the laboratory in refrigerated polyethylene bottles. These measurements were performed according to the Standard Methods for the Examination of Water and Wastewater (APHA, 1992). In order to analyse the chlorophyll- $a$ content, $500 \mathrm{~mL}$ of reservoir water was filtered through Millipore AP40 filters. After filtration, the filters were manually macerated and extracted with $90 \%$ acetone following the procedure described by Golterman et al. (1978). The trophic state index (Carlson, 1977), which uses the Total-P values, the chlorophyll- $a$ values, and the Secchi disc values, were used to assess the trophic level of the reservoirs. Values of this index equal to or less than 20 indicate ultra-oligotrophy, values between 21 and 40 indicate oligotrophy, values between 41 and 50 evidence mesotrophy, values between 51 and 60 evidence eutrophy, and values equal or greater than 61 indicate hyper-eutrophy.

\subsection{Chironomid larvae}

The chironomid larvae were treated with a $10 \%$ lactophenol solution and identified under a microscope (400x) with the aid of taxonomic keys (Trivinho-Strixino and Strixino, 1995; Epler, 2001). The occurrence of morphological deformities in the mentum was recorded and counted. All chironomids collected were analysed. The lack or excess of teeth, asymmetry, fusion, tooth malformation, and combinations of these characteristics were considered deformities. We considered the presence or absence of deformities, but did not calculate their frequencies (Dickman et al., 1992).

Sampling stations that provided samples with deformity frequencies equal to or less than $3 \%$ were considered natural, between 3 and $6 \%$ were considered altered, and impacted when the frequency of deformities exceeded $6 \%$ (Burt et al., 2003). 

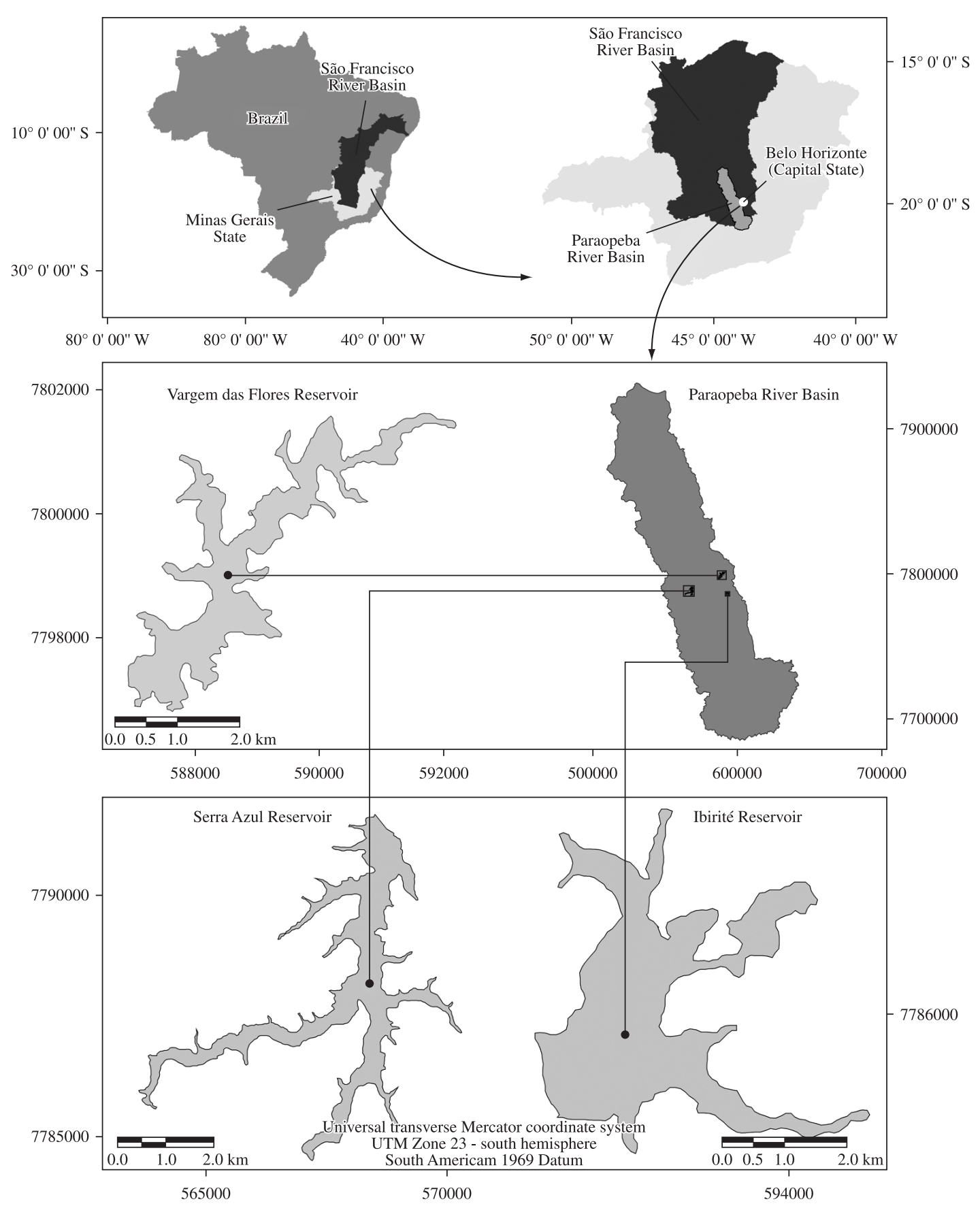

Figure 1. Map of the Serra Azul, Vargem das Flores, and Ibirité reservoirs, located in the basin of the Paraopeba River, Minas Gerais.

\subsection{Data analyses}

The Shannon-Wiener diversity index, Pielou's equitability index (Magurran, 1988), organism density (individuals/ $\mathrm{m}^{2}$ ), and taxonomic richness (total number of taxa in each sample) were calculated in order to evaluate the structure of the chironomid assemblages.

A variance analysis (ANOVA) (Software Statistica for Windows 5.1) of the data on the composition of the chironomid assemblages was used to evaluate if there were significant differences among the three reservoirs.

A cluster analysis (Software Primer 6 Beta 2004) was performed in order to assess the similarity in the taxonomic composition of the assemblages found in the three reservoirs. The Bray-Curtis index and an UPGMA (Unweighted Pair Group Method with Arithmetic Mean) were used as the amalgamation method. 
Using the three reservoirs as the groups to be indicated, an indicator species analysis (Dufrêne and Legendre, 1997) using the PC-Ord software (version 3.11, 1997) was carried out in order to establish the indicator taxa for each reservoir. The taxa that showed $\mathrm{p}$-values below $<0.05$ in a randomisation Monte Carlo test (10,000 randomisations) were considered to be indicators for one or two reservoirs.

\section{Results}

In total, 9981 organisms were collected, of which chironomid larvae represented $25.95 \%$. A total of 1697 individuals were collected in Serra Azul Reservoir (32.70\% Chironomidae), 3853 individuals in Vargem das Flores Reservoir (15.21\% Chironomidae), and 4431 individuals in Ibirité Reservoir (32.70\% Chironomidae).

A total of 2590 Chironomidae larvae were collected in the three reservoirs. The specimens belonged to 24 genera and two subfamilies: Subfamily Tanypodinae: 2 Pentaneurini genera, 2 Procladiini genera, 1 Coelotanypodini genus, and 1 Tanypodini genus; Subfamily Chironominae: 13 Chironomini genera, 3 Tanytarsini genera, and 2 Pseudochironomini genera. Members of Chironominae represented $64.05 \%$ of the individuals, whereas the Tanypodinae comprised $35.95 \%$. The 1449 individuals found in Ibirité Reservoir belonged to 11 genera, with Chironomus being the most abundant (31.43\%), followed by Coelotanypus (20.63\%), Aedokritus (16.66\%), Tanypus (14.71\%), and Tanytarsus (9.66\%). The 586 individuals collected in Vargem das Flores Reservoir belonged to 16 genera, with Coelotanypus being the most abundant (34.27\%), followed by Aedokritus (30.59\%), Pelomus (9.28\%), Djalmabatista (7.56\%), and Tanypus (4.76\%). The 555 individuals collected in Serra Azul Reservoir belonged to 20 genera, with Fissimentum being the most abundant (19.75\%), followed by Tanypus (17.07\%), Coelotanypus (15.96\%), Procladius (11.03\%), Djalmabatista (10.90\%), and Polypedilum (8.37\%) (Table 1).

Regarding the chironomid larvae, Serra Azul showed the highest values of taxonomic richness (20 taxa), Pielou's equitability (0.737), and Shannon-Wiener diversity (2.215), and the lowest total density $\left(1,494.81 \pm 2,228.16\right.$ individuals $\left./ \mathrm{m}^{2}\right)$. Vargem das Flores showed intermediate values of taxonomic richness (16 taxa), equitability (0.655), diversity (1.817), and total density $\left(1,812.22 \pm 3,945.36\right.$ individuals $\left./ \mathrm{m}^{2}\right)$. The lowest taxonomic richness (11 taxa), equitability (0.614), diversity (1.473) values, and the highest total density $\left(4,235.75 \pm 8,775.31\right.$ individuals $\left./ \mathrm{m}^{2}\right)$ value were all recorded for Ibirité (Table 1).

The values for chironomid taxonomic richness $\left(\mathrm{F}_{2.87}=4.60, \mathrm{p}=0.01\right)$, Pielou's equitability $\left(\mathrm{F}_{2.86}=4.73\right.$, $\mathrm{p}=0.01)$, and Shannon-Wiener diversity $\left(\mathrm{F}_{2.87}=3.728\right.$, $\mathrm{p}=0.02$ ) among the three reservoirs were significantly different. On the other hand, the total density values for the three reservoirs were not significantly different $\left(\mathrm{F}_{2.87}=1.63\right.$, $\mathrm{p}=0.20$ ). The taxonomic composition was significantly different among the reservoirs when the dry and the wet seasons were compared $\left(\mathrm{F}_{153.38}=3.177, \mathrm{p}=0.0016\right)$.
The analysis of indicator species showed Chironomus as the indicator taxon for Ibirité Reservoir, with an indicator value of 81 ; Pelomus as the indicator taxon for Vargem das Flores Reservoir, with an indicator value of 31 ; and Fissimentum as the indicator taxon of Serra Azul Reservoir, and an indicator value of 75. The cluster analysis showed a higher similarity between Ibirité and Vargem das Flores reservoirs, which were separated from Serra Azul Reservoir (Figure 2).

Despite the importance of identification of genera belonging to the subfamily Tanypodinae for the study of the taxonomic composition of the chironomid assemblages, deformities in mouthparts were found only among larvae belonging to the subfamily Chironominae. During the dry season in Serra Azul Reservoir, the occurrence of morphological deformities exceeded $6 \%(6.9 \%)$. In this reservoir during the wet season, and in Ibirité and Vargem das Flores reservoirs, the percentages of morphological deformities were less than $6 \%$ (Table 3 ).

Deformities in the mentum of chironomid larvae were found in the genera Aedokritus, Chironomus, Fissimentum, and Polypedilum. Aedokritus individuals with deformities were found in Ibirité and Vargem das Flores. Chironomus larvae with mentum deformities were found in all three reservoirs. Individuals belonging to the genera Fissimentum and Polypedilum that displayed morphological deformities were only found in Serra Azul.

The results of the physical and chemical analyses (Table 2) showed that the highest value for Total-P was found in Ibirité during the dry season $(229.19 \mathrm{mg} / \mathrm{L})$, and the lowest value was observed in Serra Azul during the wet season $(19.40 \mathrm{mg} / \mathrm{L})$. Intermediate values were found in Vargem das Flores $(21.41 \mathrm{mg} / \mathrm{L}$ during the dry season and $24.90 \mathrm{mg} / \mathrm{L}$ during the wet season). The highest chlorophyll- $a$ concentration was found in Ibirité during the dry season $(90.08 \mu \mathrm{g} / \mathrm{L})$, while Serra Azul showed low concentrations $(2.13 \mu \mathrm{g} / \mathrm{L})$ throughout the year, and Vargem das Flores showed intermediate concentrations

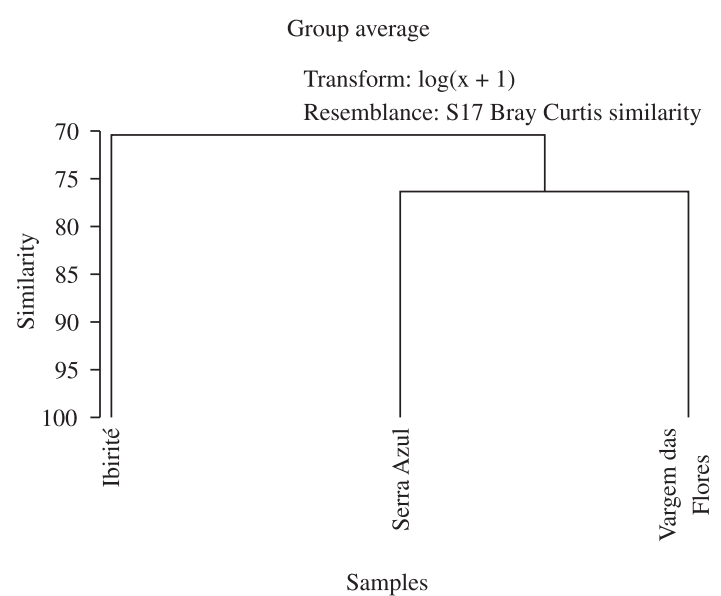

Figure 2. Similarity dendrogram for the taxonomic composition of Chironomidae found in Serra Azul, Vargem das Flores, and Ibirité reservoirs. 
Table 1. Means and standard deviations of Chironomidae larvae collected in Serra Azul, Vargem das Flores, and Ibirité reservoirs during 2008.

\begin{tabular}{|c|c|c|c|}
\hline & Ibirité & Vargem das Flores & Serra Azul \\
\hline \multicolumn{4}{|l|}{ TANYPODINAE } \\
\hline \multicolumn{4}{|l|}{ Coelotanypodini } \\
\hline Coelotanypus Kieffer,1913 & 20.63 & 34.27 & 15.96 \\
\hline \multicolumn{4}{|l|}{ Pentaneurini } \\
\hline Ablabesmyia Johannsen, 1905 & 0.97 & 0.85 & 5.90 \\
\hline Labrundinia Fittkau, 1962 & & & 0.12 \\
\hline \multicolumn{4}{|l|}{ Procladiini } \\
\hline Djalmabatista Fittikau, 1968 & & 7.56 & 10.90 \\
\hline Procladius Skuse, 1889 & & 0.74 & 11.03 \\
\hline \multicolumn{4}{|l|}{ Tanypodini } \\
\hline Tanypus Meigen, 1803 & 14.71 & 4.76 & 17.07 \\
\hline \multicolumn{4}{|l|}{ CHIRONOMINAE } \\
\hline \multicolumn{4}{|l|}{ Chironomini } \\
\hline Aedokritus Roback, 1958 & 16.66 & 30.59 & 0.37 \\
\hline Beardius Reiss et Sublette, 1985 & & 0.10 & \\
\hline Chironomus Meigen, 1803 & 31.43 & 2.25 & 3.82 \\
\hline Cladopelma Kieffer, 1921 & & 0.20 & 0.25 \\
\hline Cryptochironomus Kieffer, 1918 & & & 0.12 \\
\hline Dicrotendipes Kieffer, 1913 & 0.04 & 0.10 & \\
\hline Fissimentum Cranston \& Nolte, 1996 & & 1.25 & 19.75 \\
\hline Goeldichironomus Fittkau, 1965 & 1.18 & 2.23 & \\
\hline Pelomus Kieffer, 1921 & 2.91 & 9.28 & 1.19 \\
\hline Lauterboniella Thienemann \& Bause, 1913 & & & 1.19 \\
\hline Paralauterboniella Lenz, 1941 & & & 0.12 \\
\hline Polypedilum Kieffer, 1913 & & 4.27 & 8.37 \\
\hline Stenochironomus Kieffer, 1919 & & & 0.12 \\
\hline \multicolumn{4}{|l|}{ Pseudochironomini } \\
\hline Manoa Fittikau, 1963 & & & 0.45 \\
\hline Pseudochironomus Mallock, 1915 & & & 0.57 \\
\hline \multicolumn{4}{|l|}{ Tanytarsini } \\
\hline Tanytarsus Kieffer, 1921 & 9.66 & 1.14 & 0.74 \\
\hline Não identificados & 1.81 & 0.41 & 1.96 \\
\hline Taxonomic Richness & 11 & 16 & 20 \\
\hline Diversity & 1.473 & 1.817 & 2.215 \\
\hline Equitability & 0.614 & 0.655 & 0.737 \\
\hline Total Density (ind/m²) & $\begin{array}{c}4,235.75 \pm \\
8,775.31\end{array}$ & $\begin{array}{c}1,812.22 \pm \\
3,945.36\end{array}$ & $\begin{array}{c}1,494.81 \pm \\
2,228.16\end{array}$ \\
\hline
\end{tabular}

during both the dry $(2.67 \mu \mathrm{g} / \mathrm{L})$ and the wet $(3.55 \mu \mathrm{g} / \mathrm{L})$ seasons. The highest electrical conductivity was recorded in Ibirité during the dry season $(393.0 \mu \mathrm{S} / \mathrm{cm})$, while the lowest value was found in Serra Azul during the dry season $(29.35 \mu \mathrm{S} / \mathrm{cm})$, and intermediate values were found in Vargem das Flores during the dry $(150.43 \mu \mathrm{S} / \mathrm{cm})$ and wet $(134.0 \mu \mathrm{S} / \mathrm{cm})$ seasons.

The results found for the trophic status of the reservoirs indicated oligotrophy in Serra Azul (39.85), mesotrophy in Vargem das Flores (46.92), and eutrophy in Ibirité (69.77).

\section{Discussion}

The taxonomic composition of Chironomidae in the three reservoirs was typical of lentic ecosystems, including Fissimentum, Goeldichironomus, and Cladopelma (Strixino and Trivinho-Strixino, 1998; Leal et al., 2004).

Serra Azul Reservoir was the most diverse, in terms of both taxonomic richness (20 taxa) and Shannon-Wiener diversity (2.215). This reservoir had the genus Fissimentum, which is common in good-quality freshwaters (Leal et al., 2004), as its indicator taxon. In contrast, the chironomid 
Table 2. Means and standard deviations of physical and chemical parameters in Serra Azul, Vargem das Flores, and Ibirité reservoirs during the dry and rainy seasons in 2008.

\begin{tabular}{|c|c|c|c|c|c|c|}
\hline & \multicolumn{2}{|c|}{ Ibirité } & \multicolumn{2}{|c|}{ Serra Azul } & \multicolumn{2}{|c|}{ Vargem das Flores } \\
\hline & Dry & Rainy & Dry & Rainy & Dry & Rainy \\
\hline Depth (m) & $2.60 \pm 2.30$ & $2.80 \pm 2.88$ & $4.37 \pm 3.53$ & $5.47 \pm 3.53$ & $4.40 \pm 2.95$ & $3.81 \pm 2.01$ \\
\hline Secchi (m) & $0.51 \pm 0.37$ & $0.48 \pm 0.16$ & $2.59 \pm 0.76$ & $1.65 \pm 0.47$ & $1.21 \pm 0.51$ & $0.99 \pm 0.31$ \\
\hline Air temperature $\left({ }^{\circ} \mathrm{C}\right)$ & $27.03 \pm 2.60$ & $27.80 \pm 2.77$ & $22.80 \pm 1.14$ & $29.40 \pm 2.20$ & $25.77 \pm 3.11$ & $27.50 \pm 1.98$ \\
\hline Water temperature $\left({ }^{\circ} \mathrm{C}\right)$ & $25.20 \pm 2.20$ & $27.50 \pm 1.72$ & $23.97 \pm 1.14$ & $29.54 \pm 0.96$ & $27.16 \pm 2.80$ & $28.30 \pm 1.80$ \\
\hline $\mathrm{pH}$ & $8.20 \pm 0.99$ & $7.60 \pm 0.90$ & $7.50 \pm 0.27$ & $7.28 \pm 0.39$ & $8.29 \pm 0.29$ & $7.90 \pm 0.58$ \\
\hline Electrical conductivity $(\mu \mathrm{S} / \mathrm{cm})$ & $393.00 \pm 63.71$ & $203.20 \pm 145.30$ & $29.35 \pm 1.33$ & $33.37 \pm 11.57$ & $150.43 \pm 19.61$ & $134.00 \pm 33.27$ \\
\hline TDS (mg/L) & $336.33 \pm 45.99$ & $208.54 \pm 30.14$ & $21.60 \pm 1.45$ & $22.05 \pm 6.96$ & $120.69 \pm 31.61$ & $98.60 \pm 12.30$ \\
\hline Redox (mV) & $62.41 \pm 119.35$ & $104.66 \pm 93.30$ & $152.61 \pm 32.91$ & $187.50 \pm 67.47$ & $113.70 \pm 16.97$ & $208.33 \pm 44.37$ \\
\hline Turbidity (UNT) & $59.52 \pm 88.83$ & $99.55 \pm 1.54$ & $3.44 \pm 17.19$ & $13.12 \pm 17.19$ & $39.14 \pm 33.36$ & $47.34 \pm 41.06$ \\
\hline Dissolved oxygen (mg/L) & $7.19 \pm 2.20$ & $7.88 \pm 2.38$ & $7.40 \pm 0.96$ & $7.40 \pm 0.90$ & $7.60 \pm 1.47$ & $7.44 \pm 1.51$ \\
\hline Chlorophyll- $a(\mu \mathrm{g} / \mathrm{L})$ & $90.08 \pm 97.30$ & $2.52 \pm 27.43$ & $2.13 \pm 1.80$ & $2.13 \pm 2.08$ & $2.67 \pm 1.79$ & $3.55 \pm 2.35$ \\
\hline Total-N (mg/L) & $0.27 \pm 0.29$ & $0.29 \pm 0.16$ & $0.04 \pm 0.02$ & $0.05 \pm 0.08$ & $0.14 \pm 0.15$ & $0.36 \pm 0.30$ \\
\hline Total-P (mg/L) & $229.19 \pm 421.70$ & $130.93 \pm 180.71$ & $22.78 \pm 22.78$ & $19.40 \pm 17.80$ & $21.41 \pm 14.74$ & $24.90 \pm 19.81$ \\
\hline P-orto (mg/L) & $35.37 \pm 161.03$ & $14.72 \pm 25.20$ & $5.45 \pm 1.77$ & $5.56 \pm 1.60$ & $7.69 \pm 3.40$ & $8.08 \pm 4.54$ \\
\hline
\end{tabular}

Table 3. Percentage of the total number of mentum deformities found in larvae of the subfamily Chironominae, and total percentage of deformities found in each genus in Serra Azul, Vargem das Flores, and Ibirité reservoirs during the dry and rainy seasons in 2008 .

\begin{tabular}{|c|c|c|c|c|c|c|}
\hline & \multicolumn{2}{|c|}{ Ibirité } & \multicolumn{2}{|c|}{ Vargem das Flores } & \multicolumn{2}{|c|}{ Serra Azul } \\
\hline & Dry & Rainy & Dry & Rainy & Dry & Rainy \\
\hline CHIRONOMINAE & 1.54 & 1.48 & 2.46 & 0.80 & 6.90 & 3.29 \\
\hline \multicolumn{7}{|l|}{ Chironomini } \\
\hline Aedokritus Roback, 1958 & 3.53 & 2.80 & 4.21 & & & \\
\hline Chironomus Meigen, 1803 & 1.50 & 1.15 & & 16.66 & 16.66 & \\
\hline Fissimentum Cranston \& Nolte, 1996 & & & & & 4.76 & \\
\hline Polypedilum Kieffer, 1913 & & & & & 40.00 & 7.69 \\
\hline
\end{tabular}

assemblage in Ibirité Reservoir had the genus Chironomus as the indicator taxon, and showed low levels of taxonomic richness (11 taxa) and diversity (1.473) compared to Serra Azul Reservoir. The genus Chironomus is characterised by its tolerance to pollution and high organic-matter concentrations, thus being typical of impacted ecosystems (Devái, 1988; Marques et al., 1999; Helson et al., 2006). Vargem das Flores Reservoir showed intermediate levels of taxonomic richness (16 taxa) and diversity (1.817) compared to the other two reservoirs, and had as an indicator taxon the genus Pelomus, which is typical of clean environments (Simpson and Bode, 1980) and lives on sand substrata of lentic littoral zones (Strixino and Trivinho-Strixino, 1998).

The high abundance of individuals of the genus Fissimentum in Serra Azul is due to the fact that members of this genus are common in aquatic ecosystems where there are fluctuations of the water level (Cranston and Nolte, 1996), and are typical of lentic ecosystems that have good ecological potential (Leal et al., 2004).
Seasonal differences in the taxonomic composition and density could be explained by the different amounts of allochthonous material entering these systems. Increased input of allochthonous matter produces a decrease in organism density (Higuti and Takeda, 2002).

The high percentage of deformities found in individuals of the subfamily Chironominae in Serra Azul (>6\%) may be a response to the high concentrations of manganese $(>0.1 \mathrm{mg} / \mathrm{L}$ ) present in the sediment of this reservoir, due to the geological nature of the underlying matrix (Martins, 1996). The manganese content in this reservoir exceeds the acceptable level (CONAMA Resolution No. 357 of March $17^{\text {th }}$, Brasil, 2005) for special-class aquatic ecosystems. High concentrations of this heavy metal in the sediment of aquatic ecosystems can cause the development of morphological deformities in chironomid larvae (Janssens de Bisthoven et al., 2005). Toxic contaminants can influence the presence of chironomids because these insects depend on microhabitat structure and physico-chemical conditions; and contaminants may also cause malformations in the larvae (Nazarova et al., 2004). 
The low taxonomic richness in the sediment of Ibirité Reservoir (11 taxa) could be due to the high concentrations of chlorophyll- $a$, Total-P, and Total-N observed in the water column, which are characteristic of eutrophic ecosystems (Camargo et al., 2005). In theory, an oligotrophication of the reservoir with the consequent reduction of these parameters would favour an increase of its taxonomic richness, allowing the number of taxa to reach the levels found in Vargem das Flores (16 taxa) and Serra Azul (20 taxa).

The hypothesis of the study was partially corroborated. As expected, the results evidenced significant differences in taxonomic composition, richness, equitability, and diversity among the three reservoirs. Pollution-tolerant taxa were recognised as indicators in Ibirité and Vargem das Flores reservoirs, whereas a pollution-sensitive taxon was recognised as an indicator in Serra Azul. In addition, a low similarity in composition and distribution of the chironomid larvae was observed for Serra Azul compared to the other two reservoirs. High percentages of morphological deformities were found only in the oligotrophic reservoir, and were probably due to the high manganese content in the sediments.

Acknowledgements - The authors thank FAPEMIG for financial support, and the Manuelzão Project for support in the laboratory activities. Thanks to Ivan Monteiro, Rener Gregório, and Déborah Regina for their support during the study, and all the colleagues at the Benthic Ecology Laboratory (ICB-UFMG), and two anonymous referees for their great improvements to the text. This manuscript was the monograph of Sophia Morais (in memoriam), honoured here by her co-author friends. This paper was written while MC was a sabbatical visitor (CAPES fellowship No. 4959/09-4) at the IMAR, Universidade de Coimbra, Portugal.

\section{References}

American Public Health Association - APHA, 1992. Standard Methods for the Examination of Water and Wastewater. $18^{\text {th }}$ ed. Washington, D.C.

BARBOUR, MT., GERRITSEN, J., SYNDER, BD. and STRIBLING, JD., 1999. Rapid bioassessment protocols for use in streams and wadeable rivers: Periphyton, Benthic Macroinvertebrates and Fish. $2^{\mathrm{a}}$ ed. New York

BERG, MB. and HELLENTHAL, RA., 1992. Life histories and growth of lotic chironomids (Diptera: Chironomidae). Annals of the Entomological Society of America, vol. 85, p. 578-589.

BONADA, N., PRAT, N., RESH, V. and STATZNER, B., 2006. Developments in aquatic insects biomonitoring: A comparative analysis of recent Approaches. Annual Review of Entomology, vol. 51, p. 495-523.

BOTTS, PS., 1997. Spatial pattern, patch dynamics and successional change: chironomid assemblages in a Lake Erie coastal wetland. Freshwater Biology, vol. 37, no. 2, p. 277-286.

BRANCO, SM. and ROCHA, AA., 1977. Poluição, proteção e usos múltiplos de represas. São Paulo: Edgard Blücher/CETESB, $185 \mathrm{p}$.
BRASIL, 2005. Resolução n 357 de 17 de março de 2005 do Conselho Nacional do Meio Ambiente. Diário Oficial da União, Brasília, DF, 18 mar. Seção 1, no. 53, p. 58-63.

BURT, J., CIBOROWSKI, JJH. and REYNOLDSON, TB., 2003. Baseline incidence of mouthpart deformities in Chironomidae (Diptera) from the Laurentian Great Lakes. Canada. Journal of Great Lakes Research, vol. 29, p. 172-180.

CALLISTO, M., GONÇALVES, JF. and MORENO, P., 2005a. Invertebrados Aquáticos como Bioindicadores. In GOULART, EMA. (Eds.). Navegando o Rio das Velhas das Minas aos Gerais. p. $555-567$.

CALLISTO, M., MORENO, P., GONÇALVES, JF., FERREIRA, W. and GOMES, CLZ., 2005b. Malacological assessment and natural infestation of Biomphalaria straminea (Dunker. 1848) by Schistosoma mansoni (Sambon. 1907) and Chaetogaster limnaei (K. Von Baer. 1827) in an urban eutrophic watershed. Brazilian Journal of Biology, vol. 65, no. 2, p. 1-13.

CALLISTO, M., MORENO, P., GONÇALVES, JF., LEAL, JJF. and ESTEVES, FA., 2002. Diversity and biomass of Chironomidae (Diptera) larvae in an impacted coastal lagoon in Rio de Janeiro. Brazil. Brazilian Journal of Biology, vol. 62, no. 1, p. 77-84.

CAMARGO, JA., ALONSO, A. and DE LA PUENTE, M., 2005. Eutrophication downstream from small reservoirs in mountain rivers of Central Spain. Water Research, vol. 39, p. 3376-3384.

CARLSON, RE., 1977. A trophic index for Lakes. Limnology and Oceanography. vol. 22, no. 2, p. 361-369.

COFFMAN, WP. and FERRINGTON-JR, LC., 1996. Chironomidae. In MERRITT, RW. and CUMMINS, KW. (Eds.). An introduction to the aquatic insects of North America. Kendall: Hunt Publishing, p. 635-754.

Companhia de Saneamento de Minas Gerais - COPASA, 2004. Levantamento Batimétrico do Reservatório Serra Azul Mateus Leme e Vargem das Flores - MG. Hydrologic Data Collection. Engenharia S/C Ltda, $14 \mathrm{p}$.

CONLEY, DJ., PEARL, HW., BOESCH, DF., SEITZINGER, SP., HAVENS, KE., LANCELOT, C. and LIKENS, GE., 2009. Ecology: Controlling Eutrophication: Nitrogen and Phosphorous. Science. vol. 323, no. 5917, p. 1014-1015.

COSTA, IAS., AZEVEDO, SMFO., SENNA, PAC., BERNARDO, RR., COSTA, SM. and CHELLAPPA, NT., 2006. Occurrence of toxinproducing cyanobacteria blooms in a Brazilian semiarid reservoir. Brazilian Journal of Biology, vol. 66, no. 1b, p. 211-219.

CRANSTON, PS. and NOLTE, U., 1996. Fissimentum, a new genus of drought-tolerant chironomini (Diptera:Chironomidae) from the Americas and Australia. Entomological News, vol. 107, no. 1, p. 1-15.

DÉVAI, G., 1988. Emergence patterns of chironomids in Kesztnelybasin of Lake Balaton (Hungary). Spixiana Supplement, vol. 14, p. 201-211.

DICKMAN, M., BRINDLE, I. and BENSON, M., 1992. Evidence of teratogens in sediments of the Niagara River watershed as reflected by chironomid (Diptera: Chironomidae) labial plate deformities. Journal of Great Lakes Research, vol. 18, no. 3, p. $467-480$.

DUFRÊNE, M. and LEGENDRE, P., 1997. Species assemblages and indicator species: the need for a flexible asymmetrical approach. Ecological Monographs, vol. 67, p. 345-366. 
ENTREKIN, SA., WALLACE, JB. and EGGERT, SL., 2007. The response of Chironomidae (Diptera) to a long-term exclusion of terrestrial organic matter. Hydrobiologia, vol. 575, p. 401-413.

EPLER, JH., 2001. Identification manual for the larval Chironomidae (Diptera) of North and South Carolina. Orlando: Departament of Enviromental and Natural Resources, 495 p.

GOLTERMAN, HL., CLYMO, RS. and OHNSTAD, MAM., 1978. Methods for physical and chemical analysis of freshwaters. 2 ed. Oxford: Blackweel Scientific. Publications IBP. 8.

HELSON, JE., WILLIAMS, DD. and TURNER, D., 2006. Larval Chironomidae community organization in four tropical rivers: human impacts and longitudinal zonation. Hydrobiologia, vol. 559, p. 413-431.

HIGUTI, J. and TAKEDA, AM., 2002. Spatial and temporal variation in densities of chironomid larvae (Diptera) in two lagoons and two tributaries of the upper Paraná river floodplain. Brazil. Brazilian Journal of Biology, vol. 62, no. 4B, p. 807-818.

HURYN, AD. and WALLACE, JB., 2000. Life history and production of stream insects. Annual Review of Entomology, vol. 45 , p. $83-100$.

JANSSENS DE BISTHOVEN, L., GERHARDT, A. and SOARES, AMVM., 2005. Chironomidae larvae as bioindicatorof an acid mine drainage in Portugal. Hydrobiologia. vol. 532, p. 181-191.

JANSSENS DE BISTHOVEN, L., NUYTS. P., GODDEERIS, B. and OLLEVIER, F., 1998. Sublethal parameters in morphologically deformed Chironomus larvae: clues to understanding their bioindicator value. Freshwater Biology, vol. 39, p. 179-191.

JORCIN, A. and NOGUEIRA, MG., 2008. Benthic macroinvertebrates in the Paranapanema reservoir cascade (southeast Brazil). Brazilian Journal of Biology, vol. 68, suppl. 4, p. 1013-1024.

JORCIN, A., NOGUEIRA, MG., BELMONT, R., 2009. Spatial and temporal distribution of the zoobenthos community during the filling up period of Porto Primavera Reservoir (Paraná River, Brazil). Brazilian Journal of Biology, vol. 69, p.19-29.

KARR, JR., 1991. Biological integrity: a long-neglected aspect of water resource management. Jounal of Applied Ecology, vol. $1, \mathrm{p}$ 66-84.

LARSEN, DP., STEVENS, DL., SELLE, AR. and PAULSEN, SG., 1991. Environmental Monitoring and Assessment Program: EMAP-Surface Waters, A northeast lakes pilot. Lake and Reservoir Management, vol. 7, p. 1-11.

LEAL, JJF., ESTEVES, FA. and CALLISTO, M., 2004. Distribution of Chironomidae larvae in an Amazonian flood-plain lake impacted by bauxite tailings (Brazil). Amazoniana, vol. 18, no. $1 / 2$, p. 109-123.

LENAT, DR., 1993. Using mentum deformities of Chironomus larvae to evaluate the effects of toxicity and organic loading in streams. Jounal of the North American Benthological Society, vol. 12 , no. 3, p. 265-269.

MACDONALD, EE. and TAYLOR, BR., 2006. Incidence of mentum deformities in midge larvae (Diptera: Chironomidae) from northern Nova Scotia. Canada. Hydrobiologia, vol. 563, p. $277-287$

MAGURRAN, AE., 1988. Ecological Diversity and its Measurement. London: Princeton University Press, 179 p.

MARQUES, MMGSM., BARBOSA, FAR. and CALLISTO, M., 1999. Distribution and abundance of Chironomidae (Diptera.
Insecta) in an impacted watershed in south-east Brazil. Brazilian Journal of Biology, vol. 59, no. 4, p. 553-561.

MARTINEZ, EA., MOORE, BC., SCHAUMLOFFEL, J. and DASGUPTA, N., 2002. The potential association between menta deformities and trace elements in Chironomidae (Diptera) taken from a heavy metal contaminated river. Archives of Environmental Contamination of Toxicology, vol. 42, p. 286-291.

MARTINS, MLN., 1996. Dinâmica do ferro e do manganês no hipolímnio do Reservatório Serra Azul em Minas Gerais. Belo Horizonte.

MORENO, P. and CALLISTO, M., 2006. Benthic macroinvertebrates in the watershed of an urban reservoir in southeaster. Brazil. Hydrobiologia, vol. 560, p. 311-321.

NAZAROVA, LB., RISS, HW., KAHLHEBER, A. and WERDING, B., 2004. Some observations of buccal deformities in Chironomid Larvae (Diptera: Chironomidae) from the Ciénaga Grande de Santa Marta, Colombia. Caldasia, vol. 26, no.1, p. 275-290.

OLIVER, DR., 1971. Life history of the Chironomidae. Annual Review of Entomology, vol. 12, p. 211-230.

PAMPLIN, PAZ., ALMEIDA, TCM. and ROCHA, O., 2006. Composition and distribution of benthic macroinvertebrates in Americana reservoir (SP. Brasil). Acta Limnologica Brasiliensia, vol. 18, no. 2, p. 121-132.

PIEDRAS, SRN., BAGER, A., MORAES, PRR., ISOLDI, LA., FERREIRA, OGL. and HEEMANN, C., 2006. Macroinvertebrados bentônicos como indicadores de qualidade de água na barragem Santa Bárbara. Pelotas. RS. Brasil. Ciência Rural, vol. 36, no. 2, p. 494-500.

RODRIGUES, GA., 2004. Identificação e espacialização das Sub-bacias de maior potencial erosivo, na Bacia Hidrográfica da lagoa de Ibirité - MG. Instituto de Geociências, Departamento de Cartografia, Universidade Federal de Minas Gerais. [Monografia de Especialização].

ROQUE, FO., CORREIA, LCS., TRIVINHO-STRIXINO, S. and STRIXINO, G., 2004. A review of Chironomidae studies in lentic systems in the state of São Paulo, Brazil. Biota Neotropica, vol. 4, no. 2, p. 1-19.

ROSENBERG, DM. and RESH, VH., 1993. Freshwater Biomonitoring and Benthic Macroinvertebrates. New York: Chapman \& Hall, 488 p.

SANSEVERINO, AM. and NESSIMIAN, JL., 2008. Assimetria flutuante em organismos aquáticos e sua aplicação para avaliação de impactos ambientais. Oecologia Brasiliensis, vol. 12, no. 3, p. $382-405$.

SERVIA, MJ., COBO, F. and GONZÁLEZ, MA., 2000. Seasonal and interannual variations in the frequency and severity of deformities in larvae of Chironomus riparius (Meigen. 1804) and Prodiamesa olivacea (Meigen. 1818) (Diptera, Chironomidae) collected in a polluted site. Environmental Monitoring and Assessment, vol. 64, p. 617-626.

SIMPSON, KW. and BODE, RW., 1980. Common larvae of Chironomidae (Diptera) from New York State streams and rivers with particular reference to the fauna of artificial substrates. Buletin of the New York State Museum, vol. 439, p. 1-105.

STRIXINO, G. and TRIVINHO-STRIXINO, S., 1998. Povoamento de Chironomidae (Diptera) em lagos artificiais. In NESSIMIAN, JL. and CARVALHO, AL. (Eds.). Ecologia de Insetos Aquáticos. 
Rio de Janeiro: PPGE- UFMG, p. 141-154. Séries Oecologia Brasiliensis, vol. 5.

TAKAHASHI, MA., HIGUTI, J., BAGATINI, YM., ZVIEJKOVSKI., IP. and VELHO, LFM., 2008. Composition and biomass of larval chironomid (Insecta, Diptera) as potential indicator of trophic conditions in southern Brazil reservoirs. Acta Limnologica Brasiliensia. vol. 20, no. 1, p. 5-13.

TOKESHI, M., 1995. Life cycles and population dynamics. In: ARMITAGE, P., CRANSTON, PS. and PINDER, LCV. The Chironomidae: Biology and Ecology of Non-Biting Midges. Cornwall, UK: Chapman \& Hall, p. 3-6.

TRIVINHO-STRIXINO, S. and STRIXINO, G., 1995. Larvas de Chironomidae (Diptera) de estado de São Paulo: guia de identificação e diagnose dos gêneros. São Carlos: PPG-ERN/ UFSCAR, 229 p.

TUNDISI, J., MATSUMURA-TUNDISI, T., TUNDISI, JEM., 2008. Reservoirs and human well-being: new challenges for evaluating impacts and benefits in the neotropics. Brazilian Journal of Biology, vol. 68, no. 4, p. 1113-1135.

TUNDISI, JG., 2006. Gerenciamento Integrado de Bacias Hidrográficas e Reservatórios-Estudo de Caso e Perspectivas. In NOGUEIRA, MG., HENRY, R. and JORCIN, A. (Eds.). Ecologia de Reservatórios: impactos potenciais. ações de manejo e sistemas em cascata. São Carlos: RIMA, vol. 2, p. 1-21.

TUNDISI, JG., MATSUMURA-TUNDISI, T., ROCHA, O., ESPÍNDOLA, EL., RIETZLER, AC., IBANEZ, MS., COSTANETO, P., CALIJURI, MC. and POMPEU, M., 1998. Aquatic biodiversity as a consequence of diversity of habitats and functional mecanisms. Anais da Academia Brasileira de Ciência, vol. 70, no. 4, p. 767-773.

VERMEULEN, AC., 1995. Elaborating chironomid deformities as bioindicators of toxic sediment stress: the potential application of mixture toxicity concepts. Annales Zoologici Fennici, vol. 32, p. 265-285. 